\title{
Maulana Tariq Jameel's supplication for safety against COVID-19: A Pragmatic analysis
}

\author{
Muhammad Ali Shahid \\ Principal, the Hope College of Science \& Management, Pakistan. \\ muhammadalishshahid05@gmail.com
}

\section{Anser Mahmood}

Associate Professor, The University of Lahore Sargodha Campus, Pakistan. anser.mahmood@ell.uol.edu.pk

DOI: https://doi.org/10.18326/jopr.v4i1.1-17

Copyright (C) The Author (s)

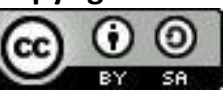

This work is licensed under a Creative Commons Attribution-ShareAlike 4.0 International License.

How to Cite: Shahid, M., \& Mahmood, A. (2022). Maulana Tariq Jameel's supplication for safety against COVID-19: A Pragmatic analysis. Journal of Pragmatics Research, 4(1). doi:https://doi.org/10.18326/jopr.v4i1.1-17

Submission
Track:
Received:
01-10-2021
Final Revision:
25-11-2021
Available online:
01-12-2021
Corresponding
Author:
Muhammad Ali Shahid
muhammadalishshahid05@gmail.com

\begin{abstract}
Supplication, the symbol of man's humility, is at the core of all religions, with Allah regarded as the Supreme Being who listens to people's prayers and rewards them accordingly, regardless of religion. The purpose of this qualitative research is to look into the unique service provided by Maulana Tariq Jameel to God for protection from COVID-19, which is currently wreaking havoc on people's lives. On April 21, 2020, the program was broadcast live on the ARY News Channel's Shab-e-Meeraj programme, hosted by Waseem Badami, and was available to watch online. Devout Muslims from all over the world gathered for a specially organised 'Dua' to demonstrate their heartfelt humility and unwavering faith in Allah, who they believe will alleviate their deathly affliction as a result of their prayers. The video at https://www.youtube.com/watch? $v=d S R u A o 14 N E I$ provided the data. The data was assessed using Aristotle's three modes of persuasion. The researchers paid close attention to the supplication during the study and coded the most relevant phrases before translating them from Urdu to English and analysed them from a pragmatic standpoint. The discussion section included references to prayers from a variety of religious traditions from various countries to integrate the study's findings. The study's findings show that when individuals, societies, or nations of any faith face a major calamity, they are more likely to be prone to Allah for protection than to other sources of protection
\end{abstract}

Keywords: Du'a, Persuasion, Religion, Staunch Faith, The sovereignty of Allah 


\section{INTRODUCTION}

This study aims to explore the concept of Supplication in Islam in general and analyse Maulana Tariq' Jameel's Supplication for protection from COVID-19, which is currently wreaking havoc on people's lives in particular. On April 21, 2020, the Supplication was broadcast live on ARY TV Channel as part of Waseem Badami's Shab-e- Meeraj program, which aired that auspicious day. Muslims from all over the world participated together in solidarity, staunchly believing in Allah's Sovereignty(Jameel, 2020). The Fifth Kalima in Islam, which speaks of man's insignificance and helplessness, as well as Allah's majesty and mercy on man's mistakes, is a powerful statement.

I ask forgiveness from Allah, my Lord, for every transgression I have committed, whether intentionally or unintentionally, secretly or openly, and I turn to Him for pardon for both known and unknown sins. Certainly You, (are) the discoverer of secret things, the concealer of errors, and the forgiver of sins. And Allah, the highest and most significant, is the only source of power and strength(6 Kalimas with Urdu Translation \& English Translation - Quran Online 786, 2018)

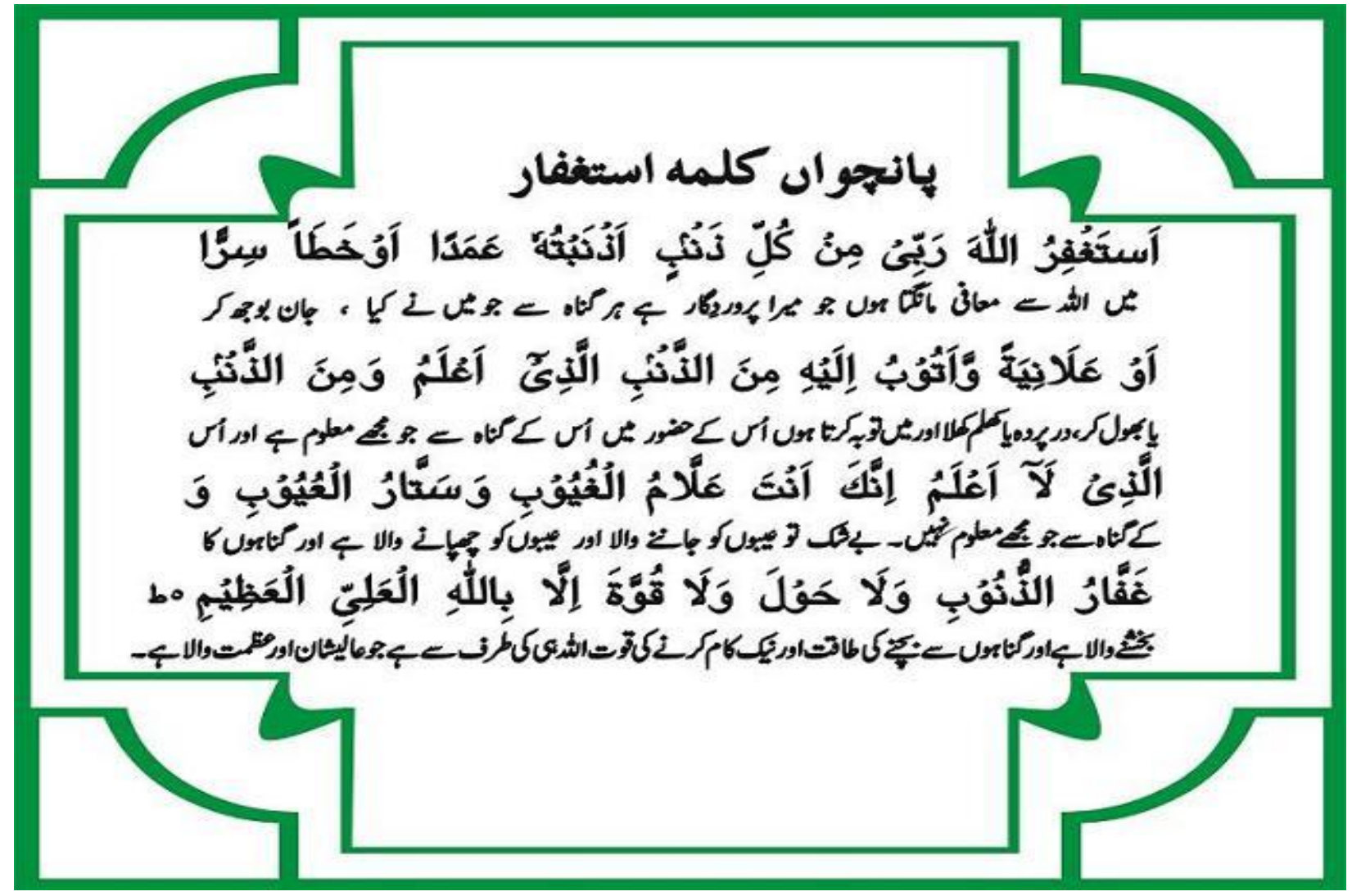

Furthermore, your Lord has stated: "Make Dua to me, and I will answer to you." Those who refuse to worship Me because they are too proud will be hurled into the flaming depths of hell, where they will be humiliated (Suratul Ghafir, Q40:60)

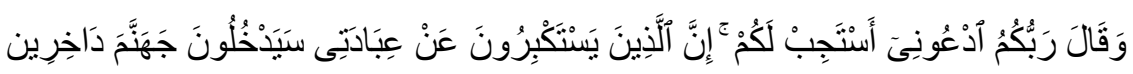


According to (Aydin, 2015), the word 'Dua' comes from the root word Du, which translates as "he called," appropriately interpreted as supplication. The term "prayer" is also commonly, but incorrectly, interpreted as such (salaat). Du'a is a method of seeking something from Allah or interacting with Him(Stands, 2018). In prayer, the supplicant asks Allah for assistance in various ways, such as protection, guidance, mercy, and so on, with the expectation and hope that his request would be fulfilled. In Islamic tradition, supplication is defined as a person presenting their entire self to God and presenting God with their bodily and spiritual demands. When it comes to worship, prayers that are performed with mindfulness serve to enhance the condition of man on the inside as well as the outside. Salaat has specific guidelines and a specific time and location where it must be offered, whereas supplication does not. In addition, while Salaat must be done in Arabic, supplication, whether as a private or informal prayer, can be said in Arabic or one's native language. Supplication can be made in any language because Allah the Almighty is All-Hearing, and it is also considered an act of worship in Islam, which implies that it is a method of purification for both the soul and the everyday life of the individual praying. The reality that human beings are creatures and, as such, bondservants of God, their Creator and the Lord, to whom they are destined to return, serves as the foundation for worshipping God. The act of man turning to God in intimate contact reverence and the spirit of devotion and humble surrender is known as worship in the Christian tradition (Davies \& Thate, 2017).

As man consciously perceives himself as being in front of God while worshipping Him, he perceives himself as being in front of God at all times, and his power over his actions limits his behaviour. The word 'Dua' is an Arabic word that has been transcribed in English letters to represent it. Three small letters come together to make a word, as well as a vast and majestic subject matter. The word 'Dua' is a plea or invocation that is loosely translated. Although neither word accurately captures the concept of Dua. Supplication, which refers to the act of conversing with a God, is more closely related to invocation, which is the act of summoning spirits or devils, respectively. In Islam, the concept of supplication is fundamental. Supplication has a plethora of advantages and virtues. Supplication is a sort of prayer offered to Allah on one's behalf. We are carrying out Allah's command by offering supplications.

Without regard for religion, nationality, or race, COVID-19 dominated the world. It caused havoc on the lives of innocent people around the planet, and it did so without the benefit of any checks or controls. Medicine, or any other form of care or therapy, is not successful in clinical trials. Was there anything people worldwide, regardless of religion, nationality, or ethnicity, could do during such a tragic and deadly period?

\section{Significance of Supplication in Islam}

The significance of prayer in Islam and any other religion cannot be denied. The question raises whom should we call for our demand except for the one who has the authority to fulfil our 
demands. Islam as well as most of the religions preaches to seek help from Allah, Almighty as the Holy Qur'an says, and 'Surely Allah is Most Capable of everything.'

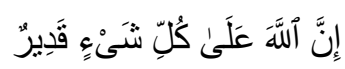

Allah says; therefore, when thou art free from your duty, still labour hard and turn (all) thy attention to thy Lord. $Q 94: 7 \& 8$.

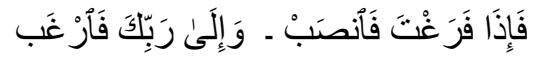

This further underlines the fact that Allah is the most effective Healer. We can always turn to Allah for help when we find ourselves in a challenging situation. Allah pays close attention to our sad stories and responds by providing us with a better answer ranging from destruction to prosperity. The time has come for us to follow His Path and demonstrate our confidence in Him by performing good deeds and abstaining from the path of Satin. Muslims must hold on to the firm belief that only one God, Allah, and no other gods (Yusuff et al., 2019)(Yusuff et al, 2019) According to the Prophet of Allah, Muhammad (PBUH), "Only through supplication can destiny be moderated." In essence, the claim is that terrible destiny can be made better via prayers, just as good destiny can be maintained with prayer. The Holy Qur'an describes the following in this context: Declare, 'O Prophet,' that My Lord has commanded uprightness and consecration to Him alone,' in worship, and that we should call upon Him with absolute devotion You will be brought back to life in the same way that He brought you into being the first time." (Surah A'raf, 29)

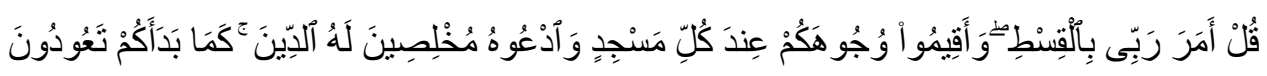

And We sent their brother Sâlih to the people of Thamûd. "O my folks!" he exclaimed. Allah should be worshipped. You have no other gods save Him. He is the One Who created you from the soil and placed you there. So, beg His pardon and turn to Him in repentance. Indeed, my Lord is always near, and he is always responsive to my prayers." (Hud: 61)

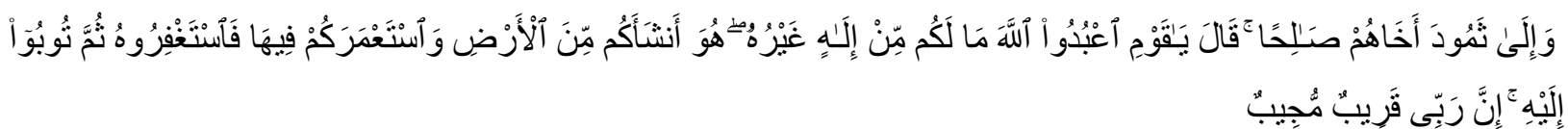

It illustrates how, in times of need and distress, we should turn to Allah for assistance. According to the Holy Prophet (SAW), "Prayer is the sword of believers," hence the only sword Muslims have to fight any problem is 'Dua.' 'Supplication is the essence of worship,' declared the prophet (PBUH). (Tirmidhi, Ibn Majah, and Ahmed)

There is a tradition that the Holy Prophet (PBUH) said: "I am to a servant of mine according to his imagination," Allah, the Exalted said. When he recalls Me, I am present with him. If he has any recollection of Me in his head. I also remember him in my memory, and if he remembers Me in the company, I remember him in a more significant company than the one in which I remember him(Al-Bukhari, 1996)When it comes to problems of the material world, it is not inappropriate to seek assistance from another being. For example, asking for help in executing certain chores such as house maintenance, automobile repair, knowledge acquisition, and so on. 


\section{Supplication by Prophets}

When the prophets of Allah were faced with complex conditions and extenuating circumstances, they would turn to Allah and express their need for Allah's assistance. As a result of their disobedience to Allah's decree, Hazrat Adam and Eve were ejected from Paradise and banished to Earth(Quran.com, 2016). They were ashamed of their actions and prayed to Allah for forgiveness for their transgression. "Our Lord!" they exclaimed in response. We have done ourselves a disservice. You have already decided that we shall be losers if You do not pardon us and have mercy on us."

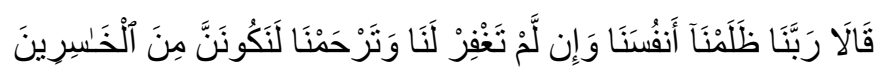

Sayyidna Zakariyya (علي السلام) wished for a son and heir for which he prayed to Allah. But at the same time, he made it clear that Allah is the best heir no matter if he had a son or not خَأنتَتَِيْر الَْارِثِنَنَ You are the best of inheritors - 21:89). This was the manifestation of the prophetic respect in that the primary concern of the prophets should always be toward Allah Ta' ala, and even if someone else came into focus, their attention should not deviate from the main objective.

Sayyidna Zakariyya (AS) desired a son and heir, and he prayed to Allah to fulfil his dream. Nonetheless, he made it plain that Allah is the finest heir, regardless of whether he had a son.

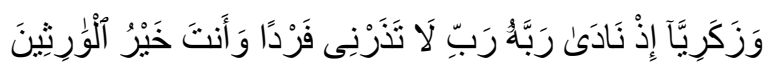

This was an expression of prophetic reverence in that the prophets' primary concern should always be toward Allah Ta' ala, and even if their attention was drawn to someone else, their attention should not be diverted from the primary goal. (Surat Anbiya: 89).

The narrative of Sayyidna Ayyub (AS) is based primarily on Jewish legends, with a few additions. The hadiths that have been deemed historically reliable by hadith scholars are those that are being reproduced here. All we know about him from the Holy Qur'an is that he was suffering from some sort of serious ailment, but that he remained strong throughout his ordeal. At the end of the day, he prayed to Allah for recovery, which Allah granted him. While he was unwell, all of his family members and friends vanished from the scene. They either died or merely left him to his destiny, depending on your perspective. Then Allah Ta'ala restored him to full health and returned all of his children to him, as well as an equal number of more children to him. The remaining components of this story have been passed down to us either through actual sayings or through historical sources, as already stated. Hazrat Ayub (AS) called out Allah in these words: And remember", when Job cried out to his Lord, "I have been touched with adversity, 1 and You, are the Most Merciful of the merciful." (Surah Anbiat, 83)

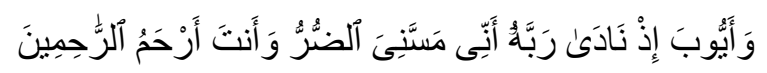

So, we answered his prayer and removed his adversity, and gave him back his family, twice as many, as a mercy from Us and a lesson for the 'devoted' worshippers. (Surah Anbiat, 84)

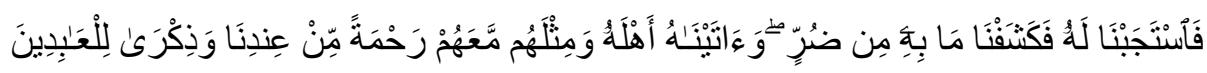


And also, when prophet Musa (AS) fled Egypt to avoid Pharaoh and was all alone in the valley of Midian, with no helper or aid he prayed: Oh my Lord! Verily I am needy to whatever good that you send down to me. So he watered 'their herd' for them, then withdrew to the shade and prayed, "My Lord! I am truly in "desperate" need of whatever provision You may have in store for me- (Surah Qasas: 24)

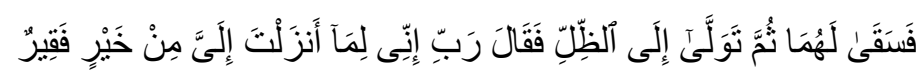

After receiving the great honour of conversing with Allah Ta'ala and being entrusted with the mission of prophethood, Sayyidna Musa (a.s.) turned to Allah Ta'ala and asked for His assistance in the performance of his duties, knowing that it would be impossible for him to endure and persevere in the face of the trials and tribulations inherent in the mission of prophethood unless Allah Ta'ala provided him with such assistance. As a result, he prayed to Allah Ta'ala, imploring him to grant him five favours. "My Lord!" Moses said in prayer. Provide comfort for me, and make my duty simple; remove any obstacle from my tongue so that others can comprehend what I'm saying." (Surah Tala, 25-28)

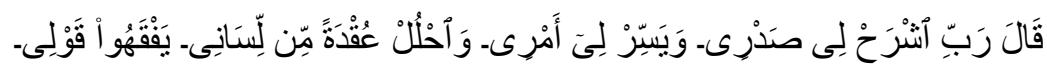

Sayyidna Ya'qub (a.s.) responded to his sons' worry by saying: "I complain of my anguish and grief not to you, nor anybody else, but to Allah jalla thana'uh Himself," which translates as "I complain of my anguish and sorrow to Allah jalla thana'uh Himself." As a result, please leave me alone as I am.' 'And, in addition to what he had stated, he also emphasised that this remembering of his would not be wasted, for Allah Ta'ala had revealed to him something that they did not know: that He had promised him that He would bring them all together with him. He replied, "I complain of my anguish and sorrow only to Allah, and I know from Allah what you do not know. (Surah Yusuf: 86)

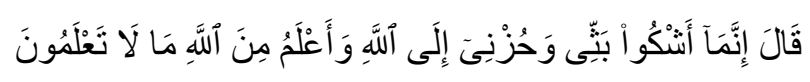

How can the Supplication be accepted?

Certain things contribute to the acceptance of a person's 'Dua' by Allah. As stated explicitly in the books of the Qur'an and Hadith, the presence of these elements increases the likelihood of one's Du'a being accepted, or at the very least increases it significantly. As a result, every person who creates Du'a must examine himself to determine whether these factors are present in him or not and if they are not, he must work hard until he incorporates all of them: Although some of these aspects have already been discussed, the following are included for the sake of completeness: To be virtuous, to have unwavering confidence in Allah, to repent of previous sins, and to present oneself modestly are all required.

Research Questions

i. Why should people seek Allah's help for safety against any Calamity?

ii. Why did people of all faiths seek Allah's help for safety against COVID-19?

iii. Why did Maulana Tariq Jameel supplicate Allah for safety against COVID-19? 
Ali ( 2014) proposes as What is Islam's perspective on substance abuse? What happens to a person's soul when they suffer from an addictive disorder? What happens to his relationship with God as a result of this? These are some of the issues that this article attempts to address. Three models of drug addiction will be examined from an Islamic theological standpoint in this article. Two of them are preventative models based on a shame-culture understanding of society, while The third, known as Millati Islami and practised in the United States, is based on the Islamic understanding of tawba (repentance). Furthermore, the role of drugs and addiction in scripture, as well as the attitudes of medieval Muslim societies toward them, are investigated. Overall, the models discussed in the article show that Islamic theology has the intellectual and theoretical tools to develop fully-fledged theological models of addiction, and the conclusion makes a suggestion to investigate one model further.

According to Hussain (2019), prayer, supplication, purification, and most ritual actions are considered acts of worship (ibadat) in Islam. The performance of the five daily prayers, known in Arabic as salah, is the most well-known and obligatory act in Islam (often written salat). The Arabic word salah means to demonstrate servitude to God through certain actions in the Qur'an.

According to (Alghafli et al., 2018), Islam is a prominent world religion with a rapidly expanding Muslim population in the West, including the United States. However, few studies have explored American Muslim families' religious practises. Researchers and the media tend to focus on religion's controversial aspects. The goal of this article is to examine the distinctive religious practice of Ramadan, particularly its perceived role on marital and familial relationships. Several themes emerged from in-depth qualitative interviews with twenty distinct Shia and Sunni Muslim families in the US $(\mathrm{N}=47)$. Data on the theme "fasting brings us closer together" are presented and explored. It appears that Ramadan is sacred to many of the 47 Muslim mothers, fathers, and youth in this study. Ramadan and family relationships are explored and explained. The research findings' implications and applications are discussed, as well as future research directions.

According to Zhou (Chen et al., 2021), prayer is an important part of many religions. Existing prayer methods were developed primarily in the Christian West, and they have emphasised various "verbal" aspects of making a supplication. Despite being essential to Muslim belief, an "active" aspect of prayer in which supplicants strive for what they pray has received insufficient attention. In addition to Muslim religiosity and spirituality, it demonstrated not only convergent validity but also incremental validity in predicting religious and psychological adjustment. Furthermore, Muslim prayers energised and integrated Muslim religious spirituality as a form of religious and psychological adjustment. This brief measure has the potential to advance empirical research on Muslim psychology and prayer research in general. 


\section{RESEARCH METHODS}

The current study used a qualitative research design to analyse the data, which was based on Maulana Tariq Jameel's prayer to Allah for help and safety from the ravages of COVID-19. The data was collected from https://www.youtube.com/watch?v=dSRuAo14NEI. The researchers carefully listened to the supplication, coded the phrases that were most relevant to the study's objectives, and translated them into English for analysis and evaluated them from a pragmatic perspective by using Aristotle's Modes of Persuasion.

\section{Modes of Persuasion}

According to Aristotle, a speaker's ability to persuade an audience is determined by how well the speaker appeals to that audience in three areas: logos, ethos, and pathos. When these appeals are considered together, they form what later rhetoricians have dubbed the rhetorical triangle (Tracy, 2019).

\begin{tabular}{l} 
Ethos: Author's credibility affects what is being said. \\
Logos: What evidence does the text provide to attest the \\
consistency? \\
Pathos: How does the text appeal to emotional \\
responses? \\
Does the text has a balanced use of Ethos, Logos and \\
Pathos or any one of these three is emphasized? \\
(Credibility) \\
(Emotions) \\
\hline
\end{tabular}

\section{Ethos}

Ethos is a Greek word that means "ethics." This term refers to the speaker's credibility. The structure of 'Ethos' comprises several elements, including the speaker's status, his knowledge and awareness of the critical matter, and professional, solid practice, making him trustworthy to the listeners and viewers.

\section{Logos}

Logos is a term of Greek origin that translates as 'logic.' When truth, proof, and evidence are provided for the research, the listeners/viewers are more likely to believe the findings.

\section{Pathos}

Pathos is a Greek term that translates literally as "emotions." This is related to the message's feasibility and effectiveness in reaching the intended audience. Pathos's appeal makes a person feel receptive to the message that has been delivered to them. 


\section{RESULT \& DISCUSSION}

\section{Ethos}

Maulana Tariq Jameel is a well-known religious scholar and preacher in Pakistan, and we are all familiar with his work. While he was still in college, he gained widespread recognition in Pakistan. He was a fantastic singer while attending Government College University in Lahore. Later, he continued his education at King Edward College, where he graduated with honours in 1988. He originally intended to pursue a medical degree, but the Islamic teachings and the religion of Islam drew him in. After that, he became well-known throughout the world. One of Maulana Tariq Jameel's friends accompanied him to the people who teach Islamic teachings and called the people to the service of ALLAH. Then he only stayed with them for three days, where he studied ISLAM from books before heading to the "Raiwind." Approximately 22 years were spent in Jamia Arabia learning Islam as well as the method of teaching Islam. He gives up his half-life to spread Islam. Maulana Tariq Jameel believes that there is a specific way to accept Islamic teachings to spread them to the general public. He began his professional career while still a student at King Edward's College in Lahore. During his college years in a Hostel, Maulana was drawn to the groups of the Tablighi Jamaat, who became his friends and helped him through his studies. He delivered lectures to students and those living in the same compound as them about Islam and Islamic teachings. The people are encouraged to follow Islamic values principles and put them into practice in everyone's life and everyday life by Maulana Tariq Jameel, who addresses them during his speech. He emphasised the importance of Islam being non-political, non-violent, and non-cliquish. Maulana Tariq Jameel has travelled to some countries to spread Islam and Islamic principles. It is estimated that he gave thousands of lectures worldwide, mostly in Muslim and European countries. He also has a good command of the Arabic language and can communicate effectively in it. The way he presents himself in public is endearing. The listener is drawn in by the speaker's commanding voice and ability to deliver religious lectures. He has quickly risen to the top of the most popular and inspirational preachers of Islam in the Urdu language. Muslims worldwide have admired and respected him as a result of his religious discourse delivered in public settings. When it comes g the lectures, Maulana Tariq Jameel has an elegant, well-spoken, and distinguished manner. He delivered lectures on the meaning of human life and the process of its creation, using scientific examples to illustrate his points. Every lecture, Maulana Tariq Jameel explains various social issues and tells us the truth about them.

Among the many people he has met and lectured with are engineers, doctors and lawyers. He has also met and spoken with entrepreneurs, landlords, actors and actresses, ministers, sports celebrities, and officials from various government agencies. Islam is in direct opposition to popular belief; Islam is a religion of supreme peace and security. In the majority of his lectures, Maulana Tariq Jameel discusses a wide range of Islamic issues as well as social teachings. He emphasised the importance of self-purification as well as the avoidance of violent methods. He 
always gave a speech to follow the Sunnah of ALLAH and his Prophet Hazrat Muhammad (PBUH) and his Companions in the Faith. Many people, both Muslims and non-Muslims, have accepted Islam as a result of his Islamic teachings and efforts, and they are working to spread Islam throughout the world. Maulana Tariq Jameel begins his professional life as a Deobandi school of thought student, which he later joined. He frequently advises Muslims to perform Tauba (which is an act of repentance for past sins and abstinence from wrong ways of life-leading) and to leave the wrong path to find the right one. The criticism of moral shamelessness, degeneration, and filthy practice that has gained a stronghold among Muslims' younger generations is something to which he is committed.

A charming personality, Maulana Tariq Jameel exudes humility and tolerance throughout his life. The fact that he is a great listener and has always provided accountable solutions to people's questions during his lectures speaks volumes about how well he is. He has combined logic and reason with religious teachings, and he has presented our religion, Islam, in a way that Muslims can understand and apply. His lectures have garnered him widespread attention, and he is now recognised as one of the world's most eminent scholars, lecturers, and preachers. Contrary to popular belief about the religion Islam, Maulana Tariq Jameel has placed a great deal of emphasis on educating people about the religion and convincing them that Islam is a religion of peace, which is contrary to popular belief. His lectures incorporate a diverse range of scientific references to satisfy the logic and reasoning aspects of the subject matter. He has always placed a strong emphasis on self-purification, rejecting violence and hate speech, and directing his hatred intently toward the remembrance of Allah (SWT) and the Sunnah of the Holy Prophet (PBUH). Today, Maulana Tariq Jameel is regarded with awe and reverence by the general public, and he occupies a prominent position on the list of the most popular speakers in the book The Muslim 500, which was published in 2013/14. As a result of the foregoing discussion, it is easy to conclude that the personality and credibility of Maulana Tariq Jameel are unquestionable and associated with worldwide fame and sublime respect in the religious spheres.

\section{Logos}

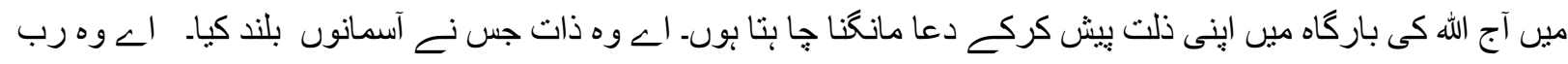

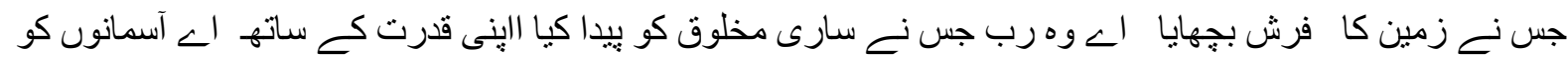

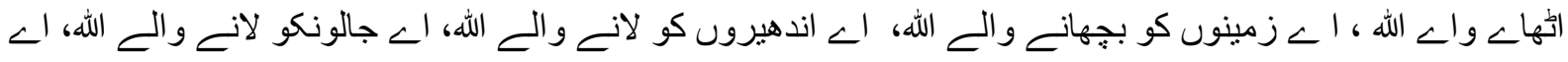

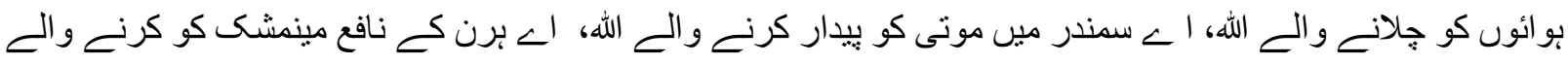

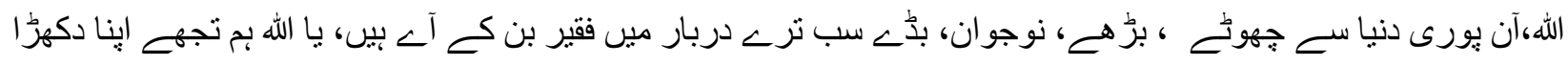

$$
\begin{aligned}
& \text { سنانا جابتخ بين- }
\end{aligned}
$$

Today, I wish to present my humiliation in Allah's sight and pray. O You Who Created the Heavens. O Lord, who expanded the earth with His power, O Lord, who created all beings. O God who raises the heavens, O God who expands the earth, O God who brings darkness, O God who brings light, O God who brings the winds, O God who creates pearls in the sea, O God who 
rewards the deer with a pungent odour in his navel. Here, people from all over the world have joined me in prayer, young and old, young and old, to become poor in the highest court, O' Allah, we want to tell you our sad story.

Explanation: Someone who is presenting and desiring to have his desires granted must first forfeit oneself of their dignity by embarrassing themselves to exhibit humility. By lowering himself to the level of the other, he accepts the other's dominance. When we pray to Allah, we acknowledge Allah's Supremacy and have a deep belief that He is the Sole Creator of the entire universe, including everything else in the universe, including man, and that He hears our prayers and responds with mercy.

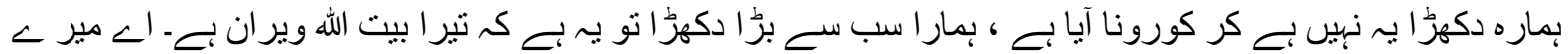

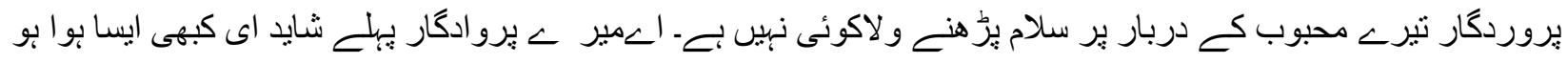

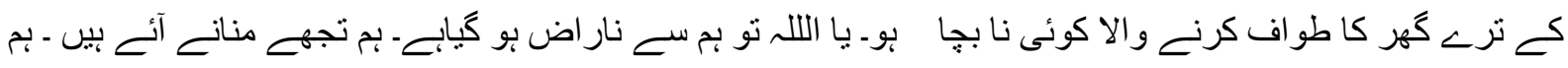

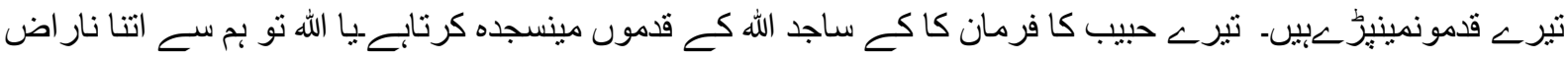

$$
\begin{aligned}
& \text { بوكيا بـ }
\end{aligned}
$$

This is not our fault; Corona has arrived, and our greatest sorrow is that the 'Baitullah' (House of God) has been deserted. There is no one to greet in the court of your Beloved, O my Lord. Oh, Lord! It had never happened before that no one performed 'Tuaf' (to make errand around Kaaba) Allah, You are furious with us. We've come to bring you joy. We're half-dead in your footsteps. Your Beloved's word is he who believes in Allah and prostrates in His feet. O' Allah! You've been so enraged with us.

Explanation: Khana Kaba is the abode of Allah, and it serves as the spiritual heart of all Muslims. The performance of a religious obligation brings Muslims from all over the world who come to 'Baitullah' with no regard to caste, socioeconomic rank, political divisions, or theological sects to fulfil their religious obligations. For Muslims, the Hajj is a condensed version of all of their religious obligations. The person who undertakes Hajj is as innocent as a newborn kid in his or her intentions. Because of the Coronavirus, it was imperative that social distancing be implemented as a precautionary measure. As a result, it was the first time that this religious responsibility was prohibited by law. Being that we are being punished for our sins, we should follow the example set by the Holy Prophet (PBUH) and prostrate ourselves before Allah to be forgiven.

An allusion to Baitullah was used for Muslim unity and humility, which they perform every year, but this time due to the ravages of Corona, they were deprived of this sacred service to Allah. Maulana admitted that it was the fault of the Muslims that they had been afflicted by the Calamity as a result of their sins. He humbly begs Allah to forgive us for the name of his Beloved Prophet Muhammad (PBUH). 


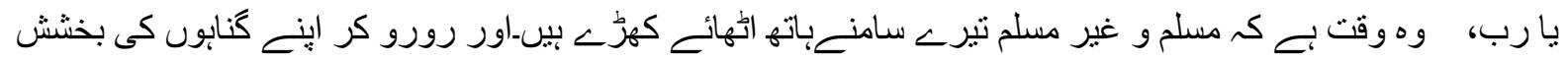

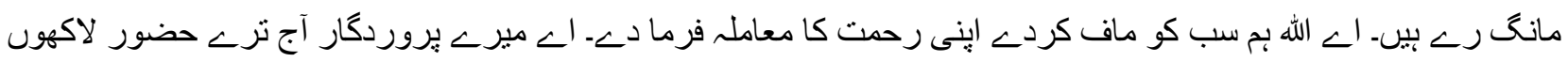

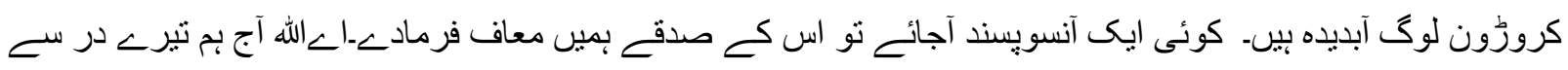

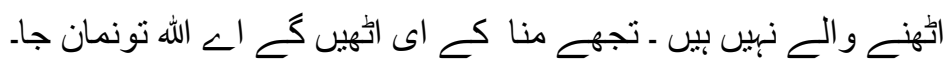

Oh, Lord! This is the time when Muslims and non-Muslims alike will be standing in front of you, hands up, wailing, and pleading for forgiveness of their sins. O Allah, forgive us all and show us mercy. Oh my Lord, there are millions upon millions of people in front of you today. If you see a crying person who inspires you, please forgive us all in his honour. We're not going to go through your door today. They will only rise if You are pleased with them, O God.

Explanation: Allah's characteristic of 'Merciful' is one of his many attributes. The one who seeks Allah's protection from sin from the depths of his heart will find that Allah hears and forgives his pleas. Coronavirus is a Holocaust that hunted both Muslims and non-Muslims alike, and it was a worldwide epidemic. Consequently, all flesh humbled before Allah to free the world of this calamity. Maulana Tariq Jameel pleaded with Allah for the sake of shedding eyes, which Allah regards as extremely valuable. In this perilous position, every human being desires the removal of this Tsunami, and they will continue to pray until Allah is satisfied with their efforts.

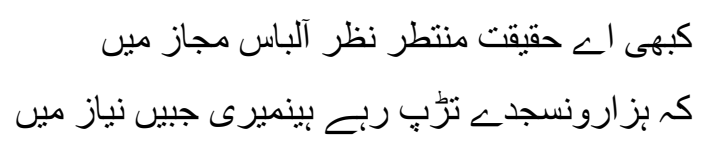

Never look forward to the reality

That thousands of prostrations are tormented in my pockets

Explanation: Never look forward to the reality of our situation; the fact is that we are sinners and that this calamity is the result of our actions. Maulana begs, although the reality is a terrible truth, O' God! Look at our humility and faith in You instead, and we believe that our prostrations will soften your heart and You will forgive us.

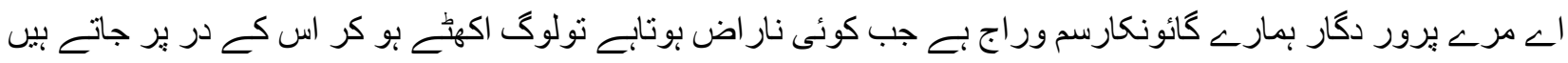

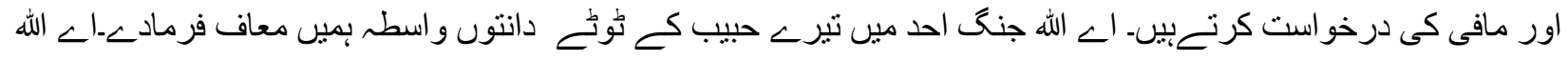

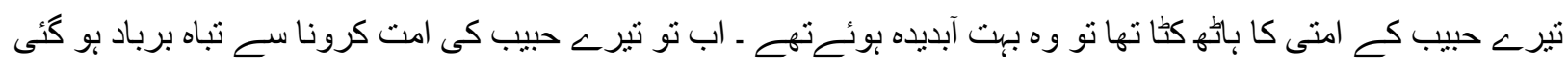

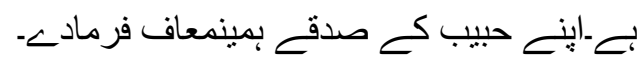

$\mathrm{O}^{\prime}$ Allah, this is a cultural norm in my village. When someone is angry, a group gathers and walks to his door to apologise for their misdoing. O Allah, forgive us for your Beloved's broken teeth in the battle of Uhud. Your Beloved's Ummah has now been devastated by 'Corona Ravages.' Forgive us for Your Beloved's kindness.

Explanation: "O Messenger! Says Allah. O, Messenger! The (message) that has been conveyed to thee from thy Lord should be proclaimed. If you had not done so, you would not have completed and announced His mission. And Allah will protect thee from men (who are out to do you harm)." (Al-Maida: 67). The fact that two teeth were broken during the Battle of Uhad does not imply that Allah did not protect them. The fact that Allah Himself declared that He would preserve His 
Prophet reveals that Allah cherished the Holy Prophet tremendously. Maulana begged Allah for protection against the Corona Pandemic by offering the sacrifice of teeth to Him.

$$
\text { ساز خاموش بيس فرياد سـ معمور بيس بم درد سناته بيس كـ مجبور بيس بم }
$$

The instruments are silent, we are full of cries

Pain stories tell that we are compelled

Explanation: The fact that the musical instruments are not playing indicates that we are not having a good time, but rather that we are in a vulnerable position due to the "Corona Raj," which is governing the world and doing havoc on the entire planet. The wailing screams and unending deaths convey the sorrowful picture of how we have no other option but to turn to You to have our prayers answered.

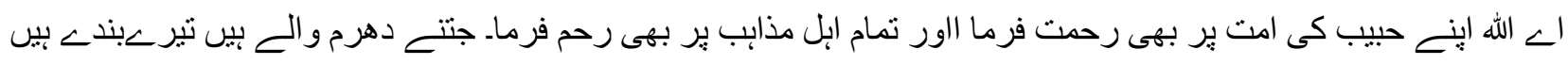

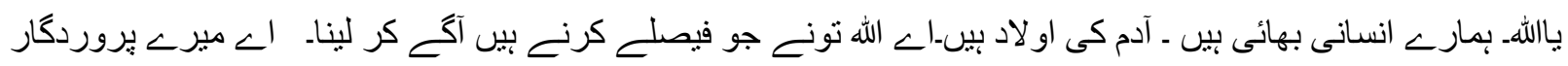

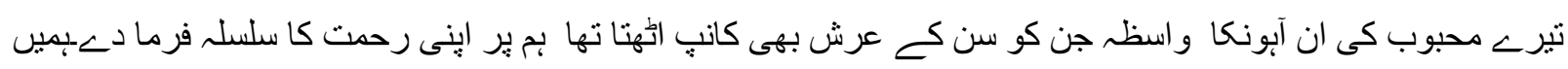

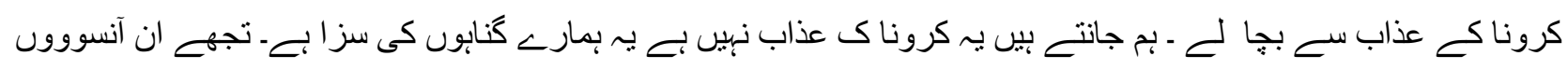

$$
\begin{aligned}
& \text { كاو اسطر جن كو سن كـ نو بيتاب بو كر جبر ائيل كو بهيجتا تها. }
\end{aligned}
$$

O Allah, pity your Beloved's Ummah and have mercy on all people of all religions. O Allah, all people of any religion are Your servants. We've got human brothers. We are Adam's descendants. $\mathrm{O}$ Allah, make the decisions that you must. O my Lord, pour upon us Thy Beloved's sighs, for whom the Throne of Hearing trembled. We understand that this is not the penalty of the 'Coronavirus,' but rather the retribution for our misdeeds. For the sake of Your Beloved Muhammad's tears, which made You restless enough to send Gabriel to discover the reason for his weeping, forgive us, O' Allah.

Explanation: We are the Ummah of Hazrat Muhammad (PBUH), who is Allah's Beloved and whom He has chosen as His Prophet. Maulana Tariq Jameel begged Allah to remember that we are all descended from Adam, as he said in his sermon. Because this catastrophe does not target a specific nation, it has wreaked havoc on both Muslims and non-Muslims equally. We understand that Your wrath is the outcome of our wrongdoings, and we are sorry for that. Because Muhammad (PBUH) holds this Ummah in high regard and has shed tears for it. Oh my God! Please accept our apologies on Muhammad's behalf.

According to the compendium of Maulana Tariq Jameel's supplication, the Corona Pandemic is a Holocaust that destroys all human beings without regard to their religious affiliation due to our wrongdoings being repaid. To combat this terrible plague, we must cease doing wrong and continue to beg Allah for protection from his Wrath. He is the Merciful, the Bountiful, and the Almighty who can heal all the sufferings. Allah will forgive us our sins in the name of His 
Beloved Prophet (PBUH). He will glance into our eyes, which are filled with tears. He will, without a doubt, hear our cries for help and provide us with refuge from the calamity.

\section{Pathos}

Menk ( 2019) writes on the 'About Islam' Web blog, 'Allah Hears Your Dua - He is Very Near.' Allah says to Muhammad in verse 186 of the chapter Al-Baqarah: "O Muhammad!" When my devotees inquire about me, please inform them that I am incredibly close.

You acquire tranquillity when you sense Allah's proximity to you. It protects you from evil, offers you hope, and transforms you into someone who looks forward to worshipping Allah and asking forgiveness.

\section{Who is the first one you call when you have a problem?}

So this verse continues as the Prophet Muhammad (peace be upon him) is told to tell us that Allah answers every caller:

\section{'I respond to every caller as he calls.}

Consider how many of us are calling for different things simultaneously, and how Allah hears and replies to everyone at the same time.

Each of us has varied problems, some of which are medical; everyone has a unique medical condition; may Allah provide us healing and may He pity those who have died. So, dear brothers and sisters, never underestimate the power of praying to Allah. During the month of Ramadan, we get up to do 'Sehar' in the morning. That is a fortunate moment. Spend some time praying to Allah. He's almost there. That is exactly what He says:

\section{'I am very near, I respond to the call of every caller when he calls out.}

May Allah's peace and blessings be upon us. Don't undervalue the power of dua. It is, certainly, a component of inner serenity. Continue to call. Recite your dua. Make a list of all of your du'a. Say that again and again throughout the year, for two years, three years... Over time, you will be able to cross items off your list. May Allah subhanahu wa ta'ala grant us goodness.

Mufti Ismail Menk is a world-renowned Islamic scholar who was born and raised in Zimbabwe. He studied Shariah in Madinah and has an Aldersgate University Doctorate in Social Guidance. Mufti Menk's work has received international acclaim, and he has been voted one of "The Top 500 Most Influential Muslims in the World" since 2010.

People throughout the world, regardless of faith or nation, are helpless as the Coronavirus wreaks havoc, and they have no other option except to turn to God for relief. Religious academics in their fold of religion bowed before God, Almighty and sound help to get rid of this dangerous Novel Coronavirus, believing God to be the All-seeing and Best Healer. Pope Francis offered his deepest gratitude to Virgin Mary on behalf of all those who have been affected by Coronavirus, as well as the many others who are enduring uncertainty as a result of their illness. He believes that Mary will shine brilliantly during her travels and will relieve the suffering of sick people(Francis, 
2020). Pastor John K. Jenkins of the First Baptist Church of Glenarden is pleading with God in the name of Jesus to end the suffering caused by Coronavirus.

He believes that God is the Supreme Being who will alleviate the suffering of sad people by providing doctors and scientists with the resources to deal with the calamity(Jerkin, 2020). A prayer for protection from the Coronavirus was sent to God by JamesParker (Parker, 2020), Staff Writer, the Atlantic. During Ramadan, an Indian police officer (YouTuble, 2021), while making a public announcement in front of a mosque, pleaded with Muslims to pray to Allah and ask for respite from the anguish that had been inflicted on them as a result of COVI-19. Maulana Tariq' Jameel's sincerely and faithfully appealed to Allah for protection against COVID-19, which is now wreaking devastation on people's life in general and the lives of children in particular. The Supplication was broadcast live on the ARY TV Channel on April 21, 2020, as part of Waseem Badami's Shab-e- Meeraj programme, which aired on that auspicious day in the Islamic calendar. Muslims from all across the world came together in solidarity, firmly believing in Allah's Sovereignty and expressing their support for the cause.

\section{CONCLUSION}

The objectives of this research were to determine why people of all religions sought Allah's assistance for safety against COVID-19, and why Maulana Tariq Jameel supplicated Allah for safety against the Con-19 virus. And why should people seek Allah's protection against any calamity in the first place? Unlike other religions, Islam has freed man from the bonds of intermediaries, thereby creating a direct link between man and his Lord and making the intercession of intermediaries unnecessary. Islam is not like other religions, in which certain places of worship have been concentrated and every other place has been prohibited. Furthermore, Islam does not restrict the practice of $\mathrm{Du}$ ' $\mathrm{a}$ ' to a certain location.

The Muslim way of life is characterised by the usage of dua, which are prayers for specific events, actions, or needs. Let us, Muslim brothers and sisters, make the act of praying a pleasure. There is no requirement for a religious leader before a person invoke the power of their creator. $\mathrm{He}$ is always accessible to take calls from anyone who needs him. Allah can be summoned from any location and at any time, regardless of the severity of a person's misdeeds, as long as he is willing to repent and seek forgiveness unless he has a partner with God. Please continue to seek God's favour at all times at all sacred places because Almighty Allah is the source of all things, a source from which everything flows, including power, wisdom, beauty, and truth. He is the only one who can ensure our safety and security. Although prayers from other religions have been included in the discussion section, the focus of this study is on Maulana Tariq Jameel's prayer in an Islamic Fold. If the study is conducted based on comparing measures with prayers from other religions, the breadth and canvas of the study will be expanded to a greater extent. 


\section{FUNDING}

Neither an influential person, nor an institution, nor a charitable organisation provided any funding for the current research.

\section{CONFLICT OF THE INTEREST}

The findings of the study suggested that the conflict has been expanded in the Islamic code of conduct addressing the necessity and significance of DUA, which may differ from that of any other religion. It is not the purpose to create religious incompatibility between people. According to their religious beliefs, people of other religions seek assistance and support in their unique way during times of crisis.

\section{ACKNOWLEDGEMENT}

To complete this scholarly work based on Religious dimensions, we would want to express our gratitude to Professor Qari Habib Ullah Habib (MPhil Urdu), Professor Hafiz Samar (B.S. Physics), and Professor Muhammad Ikram (M.A. Archaeology) for their unwavering support and collaboration.

\section{REFERENCES}

6 Kalimas with Urdu Translation \& English Translation - Quran Online 786. (2018). https://quranonline786.com/6-kalimas-with-urdu-translation-pdf/

Al-Bukhari, S. (1996). Sahih Al-Bukhari (6 Vols): Darus Salam: 9789692664745: Amazon.com: Books. https://www.amazon.com/Sahih-Al-Bukhari-Vols-Darus-Salam/dp/9692664740

Alghafli, Z., Hatch, T., Rose, A., Abo-Zena, M., Marks, L., \& Dollahite, D. (2018). A qualitative study of Ramadan: A month of fasting, family, and faith. Religions, 10(2), 123. https://doi.org/10.3390/rel10020123

Ali, M. (2014). Perspectives on drug addiction in Islamic history and theology. Religions, 5(3), 912-928. https://doi.org/10.3390/rel5030912

Aydin, H. (2015). Supplication, Prayer and the Inner Peace They Afford. The Journal of Rotterdam Islamic and Social Sciences, 4(1). https://doi.org/10.2478/jriss-2014-0005

Chen, Z. J., Tekke, M., Mastor, K. A., \& Kayadibi, S. (2021). Muslim Verbal and Active Prayer (MVAP): Measurement and Psychological Functioning of Supplications in Islam. International Journal for the Psychology of Religion, 31(4), 249-259. https://doi.org/10.1080/10508619.2020.1858254

Davies, D. J., \& Thate, M. J. (2017). Monstrosities: Religion, identity and belief. Religions, 8(6), 102. https://doi.org/10.3390/rel8060102

Francis, P. (2020). Pope Francis' prayer to Virgin Mary for protection from coronavirus - 
YouTube. https://www.youtube.com/watch?v=D2wxD3YvfeQ

Hussain. (2019). Prayer in Islam - The British Library. https://www.bl.uk/sacredtexts/articles/prayer-in-islam

Jameel, M. T. (2020). Coronavirus: Maulana Tariq Jamil Ki Khususi Dua - YouTube. https://www.youtube.com/watch?v=dSRuAo14NEI

Jerkin, P. J. K. (2020). A Prayer for a World Facing the Coronavirus (COVID-19) - Pastor John K. Jenkins Sr. - YouTube. https://www.youtube.com/watch?v=SrC9QPyfc04

Menk, D. M. (2019). Allah Hears Your Dua - He is Very Near. 186.

Parker, Jj. (2020). The Coronavirus Prayer - YouTube. https://www.youtube.com/watch?v=2iuWpt4OTEU

Quran.com. (2016). The Noble Quran - القرآن الكريم. Web Page. http://quran.com/

Stands, L. T. (2018). Definitions for dua $d u \cdot a$.

YouTuble. (2021). COVID-19: Indian police officer appeal to Muslims to pray to Allah YouTube. https://www.youtube.com/watch?v=TOVTXaRJ1Yk

Yusuff, W. N. S. B. W. M., Mokhtar, W. K. A. W., Amiruddin, E., Rashid, R. A., Idris, M. F. H. M., \& Salleh, A. Z. (2019). The Healer of all Diseases in Al-Quran: A Review. International Journal of Academic Research in Business and Social Sciences, 9(11). https://doi.org/10.6007/ijarbss/v9-i11/6576 